\title{
Prevalence and factors associated with enamel defects among preschool children from a southeastern city in Brazil
}

\author{
Prevalência e fatores associados aos defeitos de desenvolvimento \\ de esmalte em crianças pré-escolares de uma cidade \\ do sudeste do Brasil
}

\author{
Luciana Fonseca Pádua Tourino ${ }^{1}$ \\ Patrícia Maria Zarzar ${ }^{2}$ \\ Patrícia Corrêa-Faria ${ }^{2}$ \\ Saul Martins Paiva ${ }^{2}$ \\ Miriam Pimenta Parreira do Vale ${ }^{2}$
}

${ }^{1}$ Centro Universitário de Lavras. R. Padre Poggel 506, Centenário. 37200000 Lavras MG Brasil. lucianapaduatourino@ yahoo.com.br

${ }^{2}$ Faculdade de Odontologia, Universidade Federal de Minas Gerais. Belo Horizonte MG Brasil.

\begin{abstract}
This study sought to determine the prevalence of developmental defects of enamel (DDE) among preschool children and investigate associations with sociodemographic and socioeconomic factors and weight status. A cross-sectional study was conducted with 118 children aged 3 to 5 years. Data were collected via clinical examinations and a self-administered questionnaire completed by the parents. The diagnosis of DDE was performed using the modified DDE Index. Information on socioeconomic indicators (mother's schooling, monthly income per capita), child's sex and age, and age of mother at the birth of the child were obtained by questionnaire. The children's weight status was determined based on weight-for-age at the time of the exam. Statistical analysis involved the chi-squared test and Poisson regression with robust variance. The prevalence of DDE was $50.0 \%$. DDE were more frequent in males $(p=0.025)$ and children whose families were classified as being at poverty line ( $p=0.040)$. In the Poisson model controlled for child's sex and mother's schooling, children whose families were classified as being at the poverty line had a greater prevalence rate of DDE. In conclusion, the prevalence of DDE was high in the present sample and associated with lower household income. Weight status was not associated with DDE.
\end{abstract}

Key words Dental enamel, Weight by age, Child
Resumo Objetivou-se avaliar a prevalência de defeitos de desenvolvimento de esmalte (DDE) em pré-escolares e investigar a associação com fatores sociodemográficos e socioeconômicos e peso da criança. Foi realizado um estudo transversal com 118 crianças de três a cinco anos de idade. Os dados foram coletados por meio de exame clínico e questionário autoaplicável respondido pelos pais. Para o diagnóstico de DDE utilizou-se o Developmental Defects of Enamel Index. Informações sobre indicadores socioeconômicos (escolaridade da mãe e renda familiar per capita), gênero $e$ idade da criança e idade da mãe ao nascimento da criança foram obtidas do questionário. $O$ status de peso foi determinado baseando-se no peso e idade da criança no momento do exame. A análise estatística incluiu teste do qui-quadrado e regressão de Poisson. A prevalência de DDE foi $50.0 \%$, sendo mais frequente em crianças do sexo masculino $(p=0.025)$ e provenientes de famílias incluídas na linha de pobreza $(p=0.040)$. No modelo de regressão de Poisson ajustado para gênero e escolaridade da mãe, observou-se que as crianças provenientes de famílias incluídas na linha de pobreza apresentaram maior prevalência de DDE. Conclui-se que a prevalência de DDE foi alta e associada com renda familiar per capita. O peso da criança não foi associado com DDE.

Palavras-chave Esmalte dentário, Peso-idade, Criança 


\section{Introduction}

Developmental defects of enamel (DDE) result from abnormalities in the process of odontogenesis during the mineralization stage of tooth enamel and are classified as opacities consistent with hypomineralisation and hypoplasia. Opacities are characterized as a change in the translucence of the enamel and hypoplasia is evidenced by the occurrence of pits and fissures or the absence of large areas of enamel ${ }^{1}$. These defects are common in the primary dentition. According to a study conducted in Tanzania, the prevalence of DDE among children was $33.3 \%^{2}$. The prevalence of DDE was even higher among Spanish children $(40.2 \%)^{3}$. Among Brazilian children, studies have shown different prevalence values, which is worth $22.8 \%$ among Southeast children ${ }^{4}$ and $49.6 \%$ among children of the Northeast ${ }^{5}$.

DDE in the primary dentition are related to complications in the prenatal, perinatal and postnatal periods $s^{6,7}$. During the intrauterine life, the chronic deficiency of vitamins, particularly vita$\min \mathrm{D}$, is one of the factors related to the changes in the function of ameloblasts and formation of $\mathrm{DDE}^{8}$. In the perinatal period, the occurrence of DDE is associated with premature birth ${ }^{9,10}$, low birth weight status ${ }^{7,11,12}$ and breastfeeding ${ }^{7,12,13}$. In the postnatal period, DDE are associated with diseases such as infection and nutritional problems in the early years of life; moreover, the socioeconomic status of the family may predispose the primary dentition to $\mathrm{DDE}^{5,14,15}$.

Divergent opinions are found in the literature regarding the association of DDE with weight status and socioeconomic indicators. While some cross-sectional studies report a greater frequency of DDE among malnourished children ${ }^{5,6,16}$, other researchers have found no significant differences in the distribution of DDE among children with different nutritional states ${ }^{17,18}$.

The association between DDE and socioeconomic indicators has been investigated based on mother's schooling and household income. In some populations, DDE are reported to be more frequent among children from economically underprivileged families ${ }^{5}$. However, this association has not been confirmed by other researchers, who reported no differences in the distribution of DDE based on socioeconomic indicators ${ }^{9,12,19}$. The divergent findings may be related to the different indicators employed and the characteristics of the populations investigated in different studies.
Nonetheless, weight status and socioeconomic factors are known risk factors for other oral health problems, such as dental caries ${ }^{20}$. Thus, the determination of common risk factors is an adequate strategy in pediatric dentistry, allowing the prevention, identification and treatment of conditions that can affect child development. Moreover, the investigation of the association of DDE with weight status and socioeconomic indicators can furnish information on the condition of children in the early years of life and reveal possible exposure to other factors associated with DDE, such as low birth weight status, premature birth and the occurrence of infectious diseases ${ }^{7,12,16}$.

The aim of the present study was to determine the prevalence of developmental defects of enamel (DDE) among preschool children and investigate associations with sociodemographic and socioeconomic factors and weight status.

\section{Methods}

\section{Study design}

A cross-sectional study was conducted in a city of Ijaci, which is located in the state of Minas Gerais in southeastern Brazil. This city has a population of 5859 inhabitants ${ }^{21}$ and the human development index is $0.714^{22}$. The water supply does not receive fluoridation.

\section{Sample}

Initially, all children between three to five years of age enrolled at municipal schools were eligible for the study. The city has only two schools that offer preschool classes, with a total of 138 students. Both schools are public. All parents/ guardians received information regarding the objectives and procedures and those who agreed to participate signed a statement of informed consent. Children with extensive carious lesions and those with lip and/or palate abnormalities or systemic problems, such as asthma and celiac disease, which are conditions associated with DDE, were excluded from the study ${ }^{23-25}$. Other alterations related to odontogenesis (amelogenesis imperfecta and dentinogenesis imperfecta) were also considered exclusion criteria.

This study received the approval of the $\mathrm{Hu}-$ man Research Ethics Committee of the Centro Universitário de Lavras - UNILAVRAS. 


\section{Data collection}

Data collection involved dental examinations, anthropometric measurements and a self-administered questionnaire. The clinical examinations were conducted by a single trained dentist and a trained assistant recorded the observations. Prior to the fieldwork, the examiner participated in a calibration process involving images of different clinical situations. Both intra-examiner (two-week interval between two examinations) and inter-examiner (compared to an experienced expert) agreement were tested, with Kappa coefficients greater than 0.75 .

\section{Clinical examination}

The clinical examination was performed under natural light with the aid of disposable tongue depressors, standard mouth mirrors and probes. Prior to the exam, the teeth were brushed by a trained assistant and dried with gauze. During the exam the child remained seated in front of the examiner in the courtyard of the school. DDE were diagnosed based on the Modified Index of Developmental Defects of Enamel ${ }^{1}$ : demarcated opacities (coded 1), diffuse opacities (coded 2) and hypoplasia (coded 3). DDE was classified as hypoplasia when the loss of surface integrity of the enamel was observed. Opacities were characterized by a change in translucency of the enamel without affecting layer thickness. Demarcated opacities were recorded in the presence of clearly defined margins. Opacities without defined margins were recorded as diffuse ${ }^{1}$. In cases of doubt regarding the presence of abnormality and/or a tooth with a single abnormality measuring less than $1 \mathrm{~mm}$ in diameter, the tooth was classified as "normal". Teeth with up to two thirds of the crown restored and those with deep caries or fractures were not considered and received a classification of "not recorded". DDE was recorded if the child had at least one tooth with any type of enamel defect.

\section{Weight status}

Weight status was determined through the relationship between the weight status and the age of the child, comparing the measures with the standard reference values of the US National Center for Health Statistics ${ }^{26}$. The children were placed on a digital scale and weight status was registered in kilograms. The weight status and the child's age in months were identified on a child growth curve according to sex. This curve defines four weight status/age (W/A) cutoff points. Percentiles (0, 1, 3, 10 and 97) were used for the classification of weight status: W/A below the 0.1 percentile $=$ very low weight status for age; W/A greater than or equal to 0.1 and less than the third percentile = low weight status for age; W/A greater than or equal to third percentile and less than the $10^{\text {th }}$ percentile $=$ nutritional risk; W/A greater than or equal to the $10^{\text {th }}$ percentile and less than $97^{\text {th }}$ percentile $=$ adequate weight status for age; W/A greater than or equal to the $97^{\text {th }}$ percentile $=$ risk of overweight status/ obesity.

\section{Socioeconomic status}

A questionnaire addressing socioeconomic indicators (monthly income per capita and mothers' schooling), child's sex and age, and mother's age at the birth of the child was sent to the parents/guardians. The variables defined by the Brazilian National Household Survey ${ }^{27}$ and the criteria for the definition of the poverty line used by the Brazilian Institute of Applied Economic Research ${ }^{28}$ were used to characterize the socioeconomic status of the sample. Monthly income per capita was determined by the sum of all incomes of the members of the family in the month prior to filling out the questionnaire divided by the number of members. Families were classified as being below the poverty line (income per capita lower than 25\% of the Brazilian minimum wage), at the poverty line (income per capita lower than $50 \%$ of the minimum wage) or above the poverty line (income per capita $\geq 50 \%$ of the minimum wage).

\section{Data analysis}

Data analysis was performed using the Statistical Package for Social Sciences (SPSS for Windows, version 17.0, SPSS Inc., Chicago, USA). Associations between DDE and the independent variables were determined using the chi-squared test. Poisson regression with robust variance was performed for the analysis of factors associated with DDE. The magnitude of the association of each factor with DDE was assessed using non-adjusted and adjusted prevalence ratios (PR), respective 95\% confidence intervals (CI) and p-values (Wald test). Explanatory variables with a $\mathrm{p}$-value of $\leq 0.25$ in the bivariate analysis were incorporated into the model. 


\section{Results}

Of the 138 children invited to participate in this study, $122(88.4 \%)$ returned the questionnaire and informed consent form. Data from 2 (1.6\%) children were lost during data collection, because of their absence from school. Of the remaining 121 children, 118 were examined for DDE - 2 could not be examined because they had extensive carious lesions.

Mean age was 4.23 years (standard deviation: 0.61 years). Table 1 shows the sociodemographic and socioeconomic characteristics and weight status of the sample.

The prevalence of DDE was $50.0 \%(n=59)$. The most frequent type was demarcated opacity (31.4\%), followed by diffuse opacity (18.6\%) and hypoplasia (5.9\%). Some children (5.9\%) had more than one type of enamel defect. DDE were dichotomized as present or absent and comparisons were made in relation to the characteristics of the children, mothers and socioeconomic aspects. DDE were significantly associated with child's sex ( $\mathrm{p}=0.025)$ and income per capita ( $\mathrm{p}$ $=0.040)$ in the bivariate or univariate analysis. Male children and those whose families were classified as being at the poverty line had a greater number of teeth affected by DDE. No statistically significant associations were found regard-

Table 1. Sample distribution according to demographic and socioeconomic characteristics and weight status. Ijaci, Brazil, $2013(\mathrm{n}=118)$.

\begin{tabular}{lc}
\hline & $\mathbf{n}(\%)$ \\
\hline Child's sex & \\
Female & $48(40.7)$ \\
Male & $70(59.3)$ \\
Weight status & \\
$\quad$ Overweight status/obesity & $18(15.2)$ \\
Ideal range & $96(81.4)$ \\
$\quad$ Nutritional risk, underweight status & $4(3.4)$ \\
or very low weight status & \\
Income per capita (socioeconomic & \\
classification)* & \\
Below poverty line & $38(33.6)$ \\
At poverty line & $37(32.8)$ \\
Above poverty line & $38(33.6)$ \\
Mother’s schooling & \\
$>8$ years & $67(56.8)$ \\
$\leq 8$ years & $51(43,2)$ \\
\hline
\end{tabular}

* No information was obtained on income from five families $(4.2 \%)$. ing child's age, weight status, mother's schooling or mother's age at birth of the child (Table 2).

In the adjusted Poisson regression model, income per capita at the poverty line (PR: 1.259; 95\%CI: $1.00-1.57)$ remained associated with a greater prevalence of DDE independently of child's sex and mother's schooling (Table 3).

\section{Discussion}

The prevalence of DDE in the present sample was $50.0 \%$ and these defects were more frequent among children whose families were classified as being at the poverty line. This prevalence rate is similar to that reported in study involving children aged 16 to 18 months from low-income families in the city of João Pessoa in the northeastern region of Brazil ${ }^{5}$. Other investigations involving Tanzanian and Spanish children reported lower prevalence rates ${ }^{2,3}$. However, the comparison of the findings should be performed with caution due to the differences in the age of the children.

The occurrence of DDE was greater among economically more vulnerable children. According previous studies, children exposed to unfavorable socioeconomic conditions may have compromised development, including oral aspects, as such children are more prone to low birth weight status, premature birth and nutritional problems during the period of enamel formation of deciduous teeth, which are associated with $\mathrm{DDE}^{6,12}$. The present findings seem to confirm this hypothesis, as children from families with a lower income had a greater frequency of DDE.

A study conducted in Tanzania involving children aged 6 to 36 months found an association between DDE and the household assets index ${ }^{2}$. However, the socioeconomic indicators employed in the study differed from those of the present investigation, which limits the comparison of the findings.

In the present study, income per capita and mother's schooling were used as socioeconomic indicators. The lack of an association between DDE and mother's schooling is in agreement with a previous study conducted in Brazil involving children aged three to five years ${ }^{12}$. Divergences are found in the literature regarding the association with income, which may be explained by the different forms of evaluating this variable, such as monthly household income ${ }^{12}$ or monthly income per capita ${ }^{5}$. 
Table 2. Distribution of DDE according to characteristics related to children, mothers and socioeconomic aspects.

\begin{tabular}{|c|c|c|c|}
\hline & \multicolumn{2}{|c|}{ DDE } & \multirow{2}{*}{$\mathbf{p}^{*}$} \\
\hline & Absent n (\%) & Present n (\%) & \\
\hline Child's age & & & $0.457^{\mathrm{a}}$ \\
\hline 3 years & $4(33.3)$ & $8(66.7)$ & \\
\hline 4 years & $35(52.2)$ & $32(47.8)$ & \\
\hline 5 years & $20(51.3)$ & $19(48.7)$ & \\
\hline Child's sex & & & $0.025^{\mathrm{b}}$ \\
\hline Female & $30(62.5)$ & $18(37.5)$ & \\
\hline Male & $29(41.4)$ & $41(58.6)$ & \\
\hline Nutritional status & & & $0.377^{\mathrm{a}}$ \\
\hline Overweight/obesity & $9(50.0)$ & $9(50.0)$ & \\
\hline Ideal range & $50(52.1)$ & $46(47.9)$ & \\
\hline Nutritional risk, underweight or very low weight & $0(0.0)$ & $4(100.0)$ & \\
\hline Mother's age at birth of child & & & $0.322^{\mathrm{b}}$ \\
\hline$\leq 30$ years & $50(52.6)$ & $45(47.4)$ & \\
\hline$>30$ years & $9(40.9)$ & $13(59.1)$ & \\
\hline Income per capita (socioeconomic classification) & & & $0.040^{\mathrm{a}}$ \\
\hline Below poverty line & $16(42.1)$ & $22(57.9)$ & \\
\hline At poverty line & $15(40.5)$ & $22(59.5)$ & \\
\hline Above poverty line & $25(65.8)$ & $13(34.2)$ & \\
\hline Mother's schooling & & & $0.193^{b}$ \\
\hline$>8$ years & $37(55.2)$ & $30(44.8)$ & \\
\hline$\leq 8$ years & $22(43.1)$ & $29(56.9)$ & \\
\hline
\end{tabular}

${ }^{*} \mathrm{p}<0.05$; 'Linear trend chi-squared test; ${ }^{\mathrm{b}}$ Pearson's chi-squared test.

Table 3. Prevalence ratios and confidence intervals for associations between DDE and associated variables.

\begin{tabular}{lcccccc}
\hline \multicolumn{1}{c}{ Variables } & PR unadjusted & $\mathbf{9 5 \%} \mathbf{C I}$ & p-value & PR adjusted & $\mathbf{9 5 \%}$ CI & p-value \\
\hline Income per capita & & & & & & \\
Below poverty line & 1.267 & $1.01-1.57$ & 0.033 & 1.229 & $0.98-1.53$ & 0.071 \\
At poverty line & 1.287 & $1.03-1.60$ & 0.024 & 1.259 & $1.00-1.57$ & 0.044 \\
Above poverty line & 1 & - & - & - & - & \\
Child's sex & 1 & - & - & 1 & - & \\
$\quad$ Female & 1.235 & $1.03-1.46$ & 0.021 & 1.196 & $0.99-1.44$ & 0.064 \\
Male & & &
\end{tabular}

PR: Prevalence ratio; CI: confidence interval; model adjusted for mother's schooling.

In the present study, weight status was not associated with DDE, in agreement with data reported by Hanser-Ducatti et al. ${ }^{18}$, however in contradiction, a positive association is described in the literature ${ }^{29}$.

The lack of an association in the present study may be explained by the small number of children with low weight and the fact that weight status was evaluated after the formation of the primary teeth ${ }^{12}$. Another aspect that merits consideration is the fact that the weight status for age was determined at the time of the exam. This method allows the determination of nutritional risk, but does not allow the determination of malnutrition, which is a pathological process that cannot be confirmed by these anthropometric measures.

The bivariate analysis showed that sex was significantly associated with DDE. However, no significant sex difference was found regarding the frequency of DDE in the multivariable analysis, which is in agreement with findings described in previous studies ${ }^{12,16,30}$, although DDE have been reported to be more common among males. Age also exerted no influence on the distribution of DDE in the present sample, which may be explained by the period of primary tooth enamel formation. Primary tooth enamel begins form- 
ing in the womb at approximately 15 weeks of gestation and extends through to months after the child is born ${ }^{31}$. Since the children were aged three to five years, the enamel defects were already present and were therefore not influenced by this variable.

The present findings should be evaluated with caution. The cross-sectional design only allows the determination of factors associated with DDE and does not permit the establishment of causality. The sample of 118 preschool children was small in comparison to the sample sizes in other epidemiological studies, which may limit the external validity of the associations. Moreover, as conve- nience sampling was performed, the findings are only valid for the study population analyzed.

\section{Conclusion}

The prevalence of enamel defects was high in the present sample (50.0\%) and associated with lower household income. Weight status was not associated with DDE. The present findings can contribute toward directing health resources toward economically less privileged regions, as the children in these regions may be prone to the development of enamel defects.

\section{Collaborations}

All the authors contributed in preparing the article. LFP Tourino worked on the project design, collectd and organized the data as well as the writing, revision, and final approval of this article. PM Zarzar contributed towards the project and overall outline as well as provided a critical review of the manuscript. P Corrêa-Faria took part in the analyses and interpretation of data and preparation of this manuscript. SM Paiva and MPP Vale participated in the critical revision and final approval of the text to be published. 


\section{References}

1. A review of developmental defects of the enamel dental index (DDE index). Commission on Oral Health Research \& Epidemiology Report of an FDI Working Group. Int Dent J 1992; 42(6):411-426.

2. Masumo R, Bårdsen A, Astrom AN. Developmental defects of enamel in primary teeth and association with early life course events: a study of 6-36 month old children in Manyara, Tanzania. BMC Oral Health 2013; 13- 21.

3. Robles MJ, Ruiz M, Bravo-Peres M, Gonzáles E, Peñalver MA. Prevalence enamel defects in primary and permanent teeth in a group of schoolchildren from Granada (Spain). Med Oral Patol Oral Cir Bucal 2013; 18(2):187-193.

4. Correa-Faria P, Gonçalves SP, Paiva SM, Martins-Junior PA, Vieira-Andrade RG, Marques LS, Ramos-Jorge ML. Dental caries, but not malocclusion or developmental defects, negatively impacts preschoolers' quality of life. Int J Paediatr Dent 2016; 26(3):211-219.

5. Massoni AC, Chaves AM, Rosenblatt A, Sampaio FC, Oliveira AF. Prevalence of enamel defects related to pré-, peri- and postnatal factors in a Brazilian population. Community Dent Health 2009; 26(3):143-149.

6. Massoni AC, Oliveira AF, Chaves AM, Sampaio FC, Rosenblatt A. Socioeconomic factors, nutritional risk, and enamel defects in children from João Pessoa, Paraíba State, Brazil. Cad Saude Publica 2007; 23(12):29282937.

7. Ghanim A, Morgan M, Mariño R, Bailey D, Manton DJ. Risk factors of hypomineralised second primary molars in a group of Iraqi schoolchildren. Eur Arch Paediatr Dent 2012; 13(3):111-118.

8. Funakoshi Y, Kushida Y, Hieda T. Dental observations of low birth weight status infants. Pediatr Dent 1981; 3(1):21-25.

9. Cruvinel VR, Gravina DB, Azevedo TD, Rezende CS, Bezerra AC, Toledo OA. Prevalence of enamel defects and associated risk factors in both dentitions in preterm and full term born children. J Appl Oral Sci 2012; 20(3):310-3177.

10. Pinho JR, Filho FL, Thomaz EB, Lamy ZC, Libério SA, Ferreira EB. Are low birth weight status, intrauterine growth restriction, and preterm birth associated with enamel developmental defects? Pediatr Dent 2012; 34(3):244-248.

11. Velló MA, Martínez-Costa C, Catalá M, Fons J, Brines J, Guiiarro-Martínez R. Prenatal and neonatal risk factors the development of enamel defects in low birth weight status children. Oral Dis 2010; 16(3):257-262.

12. Correa-Faria P, Martins-Júnior PA, Vieira-Andrade RG, Oliveira-Ferreira F, Marques LS, Ramos-Jorge ML. Developmental defects of enamel in primary teeth: prevalence and associated factors. Int J Paediatr Dent 2013; 23(3):173-179.

13. Lunardelli SE, Peres MA. Breast-feeding and mother-child factors associated with developmental enamel defects in the primary teeth of Brazilian children. $J$ Dent Child 2006; 73(2):70-78.
14. Rugg-Gunn AJ, Al-Mohammadi SM, Butler TJ. Malnutrition and developmental defects of enamel in 2- to 6-year-old Saudi boys. Caries Res 1998; 32(3):181-192.

15. Takaoka LA, Goulart AL, Kopelman BI, Weiler RM. Enamel defects in the complete primary dentition of children born at term and preterm. Pediatr Dent 2011; 33(2):171-176.

16. Chaves AMB, Oliveira AFB, Rosenblatt A. Enamel defects and its relation to life course events in primary dentition of Brazilian children: a longitudinal study. Community Dent Health 2007; 24(1):31-36.

17. Li Y, Navia JM, Bian JY. Prevalence and distribution of developmental enamel defects in primary dentition of Chinese children 3-5 years old. Community Dent Oral Epidemiol 1995; 23(2):72-79.

18. Hanser-Ducatti C, Puppin-Rontani RM, Bastos HD, Carvalho LR. Relationship between the nutritional status and dental enamel alterations in schoolchildren Botucatu-SP. Cienc Odontol Bras 2004; 7(1):84-92.

19. Correa-Faria P, Paixão-Gonçalves S, Paiva SM, Pordeus IA, Marques LS, Ramos-Jorge ML. Association between developmental defects of enamel and early childhood caries: a cross-sectional study. Int J Paediatr Dent 2015; 25(2):103-109.

20. Oliveira LB, Sheiham A, Bönecker M. Exploring the association of dental caries with social factors and nutritional status in Brazilian preschool children. Eur J Oral Sci 2008; 116(1):37-43.

21. Instituto Brasileiro de Geografia e Estatística (IBGE). Cidades: Minas Gerais: Ijaci. Rio de Janeiro: IBGE; 2010. [Internet]. [cited 2013 May 03]. Available from: http://www.cidades.ibge.gov.br/painel/painel. php?lang=\&codmun $=313040 \&$ search $=\mid$ ijaci

22. Programa das Nações Unidas para o Desenvolvimento (PNUD). Atlas de Desenvolvimento Humano no Brasil. Brasília: ONU; 2013.

23. Gomes AC, Neves LT, Gomide MR. Enamel defects in maxillary central incisors of infants with unilateral cleft lip. Cleft Palate Craniofac J 2009; 46(4):420-424.

24. Jälevik B, Norén JG, Kingberg G, Barregard L. Etiologic factors influencing the prevalence of demarcated opacities in permanent first molar in a group of Swedish children. Eur J Oral Sci 2001; 109(4):230-234.

25. Rashid M, Zarkadas M, Anca A, Limeback H. Oral manifestations of celiac disease: a clinical guide for dentists. J Mich Dent Assoc 2011; 93(10):42-46.

26. Hanill PVV, Drizd TA, Johnson CL, Reed RB, Roche AF, Moore WM. Physical growth: National Center for Statistic Percentiles. Amer J Clin Nutr 1979; 32(3):607-629.

27. Instituto Brasileiro de Geografia e Estatística (IBGE). Pesquisa Nacional por Amostra de Domicílios. Síntese de indicadores. Rio de Janeiro: IBGE; 2009.

28. Instituto de Pesquisa Econômica Aplicada (IPEA). Dimensão, evolução e projeção da pobreza por região e por estado no Brasil. Comunicados do IPEA. n.58. Brasília:IPEA; 2010.

29. Seow WK. Enamel hypoplasia in the primary dentition: a review. ASDC J Dent Child 1991; 58(6):441-452. 
30. Oliveira AFB, Chaves AMB, Rosenblatt A. The influence of enamel defects on the development of early childhood caries in a population with low socioeconomic status: a longitudinal study. Caries Res 2006; 40(4):296-302.

31. Rythén M, Sabel N, Dietz W, Robertson A, Norén JG. Chemical aspects on dental hard tissues in primary teeth from preterm infants. Eur J Oral Sci 2010 118(4):389-395.

Artigo apresentado em 20/01/2016

Aprovado em 25/07/2016

Versão final apresentada em 27/07/2016 